\title{
RITUAL AGAMA DAN HARMONI SOSIAL KAUM URBAN: KAJIAN SOSIOLOGIS TERHADAP MUJAHADAH WARGA DI PERUM PANDANA MERDEKA NGALIYAN SEMARANG
}

\author{
Sedya Pangasih ${ }^{1 *}$, Luthfi Rahman ${ }^{2}$ \\ ${ }^{1}$ Universitas Islam Negeri Walisongo Semarang, INDONESIA \\ ${ }^{2}$ Universitas Islam Negeri Walisongo Semarang, INDONESIA \\ * Correspondence: $\otimes$ sedya_1804016014@student.walisongo.ac.id
}

\begin{abstract}
One of the Pandana Merdeka housing estates which has tried to instill harmony between communities with one another. One of the socializing activities of this housing is through mujahadah activities. This activity is very important to socialize in shaping the socio-religious aspects. The research method used is qualitative research using a sociological approach to religion. The results of this study indicate that Emile Durkheim's opinion regarding his observations about the religious phenomenon of Aboriginal groups in Australia is evident in the Pandana Merdeka housing community. This group phenomenon has the function of interacting with society in a moral order. As in the structure of the members of the Pandana Merdeka Housing community, each of them has a role in compiling the moral order through sacred ritual activities as collective action that reflects group solidarity.
\end{abstract}

\section{Article History}

Received: 09-10-2020,

Revised: 23-12-2020,

Accepted: 31-12-2020

Keywords:

Mujahadah;

Pandana Merdeka Housing;

Social Harmony

\section{Abstrak}

Salah satu perumahan Pandana Merdeka yang telah berusaha menanamkan harmonisasi antar masyarakat satu sama lain. Perumahan ini dalam bersosialisasi salah satunya melalui kegiatan mujahadah. Kegiatan ini, sangat penting untuk bersosialisasi dalam membentuk aspek sosial keagamaan. Metode penelitian yang digunakan adalah penelitian kualitatif dengan menggunakan pendekatan sosiologi agama. Hasil penelitian ini menunjukan bahwa pendapat Emile Durkheim mengenai pengamatannya tentang fenomena keagamaan kelompok Aborigin di Australia terbukti dalam masyarakat perumahan Pandana Merdeka. Fenomena kelompok tersebut memiliki fungsi mengintegrasikan masyarakat dalam suatu tatanan moral. Sebagaimana dalam tatanan anggota masyarakat Perumahan Pandana Merdeka, masing-masing mempunyai peran dalam menyusun tatanan moral tersebut melalui aktivitas ritual suci sebagai tindakan kolektif yang mencerminkan solidaritas kelompok.

\section{Histori Atikel}

Diterima : 09-10-2020,

Direvisi : 23-12-2020,

Disetujui : $31-12-2020$,

\section{Kata Kunci:}

Harmoni Sosial;

Mujahadah ;

Perumahan Pandana

Merdeka

\section{(C) 2020 Sedya Pangasih, Luthfi Rahman}

This work is licensed under a Creative Commons Attribution-ShareAlike 4.0 International License.

\section{A. Pendahuluan}

Indonesia, banyak orang yang menjulukinya sebagai negara majemuk. Hal ini terlihat dari banyaknya agama, kepercayaan, tradisi, kesenian, etnis, dan kultur. Hilderd Geertz dalam Balitbang Kemenag RI menggambarkan keragaman kemajemukan Indonesia dengan negara yang mempunyai lebih dari 300 etnis dengan budaya masing-masing, dan 250 jenis bahasa yang dipakai. ${ }^{1}$

1 Puslitbang Kehidupan Keagamaan Badan Litbang dan Diklat Kementerian Agama RI, Dinamika Sistem Keagamaan Lokal Di Indonesia (Jakarta: Badan Litbang dan Diklat Kementerian Agama RI, 2012), hlm. 11. 
Indonesia, juga dikatakan sebagai Islam sinketris, mendapatkan apresiasi yang luar biasa dari penduduk dunia. Sebagai agama mayoritas, Islam di Indonesia mengalami akulturasi dalam perkembangannya. Islam muncul di tengah-tengah masyarakat melalui pertemuannya dengan budaya lokal, yang berarti bahwa tampilan Islam bukan dengan muka Islam seutuhnya, melainkan ada polesan budaya di dalamnya. ${ }^{2}$ Clifford Greetz menegaskan, bahwa membaca esensi agama harus membaca hubugannya dengan budaya sekitar. ${ }^{3}$ Hal ini mengindikasikan bahwa agama, tradisi, dan budaya sebenarnya saling bersinggungan.

Fenomena interaksi masyarakat dengan agama dan tradisi pada realitasnya memiliki konsepsi variatif dan dinamis. Respon masyarakat tehadap agama dan tradisi sangat dipengaruhi oleh model berfikir dan konteks sosio-kultural yang mengitarinya. Beragam respon tersebut disinyalir sebagai bentuk ketakwaan. Selain itu juga, respon terhadap agama dan tradisi dipresepsikan sebagai sebuah pemuas kebutuhan, mengingat, kebutuhan manusia terdiri dari dua hal, yakni kebutuhan jasmani dan ruhani.

Kebutuhan jasmani atau biasa juga disebut sebagai kebutuhan duniawiyah ialah kebutuhan manusia yang bersifat fisik seperti makan, minum, kesehatan, dan kebutuhan yang bersifat material lainnya. Sedangkan kebutuhan ruhani atau yang biasa disebut sebagai kebutuhan ukhrawiyah adalah kebutuhan yang bersifat batin atau jiwa, seperti ketentraman hati, kebahagiaan jiwa, dan adanya well-being pada diri. ${ }^{4}$ Manusia memenuhi dua kebutuhan tersebut dalam rangka tercapainya kebahagiaan dunia dan akhirat. Untuk mewujudkan ketenangan jiwa dan hati salah satunya adalah dengan berdzikir. Sebagaimana firman Allah dalam QS. Ar-Ra'd (13): 28

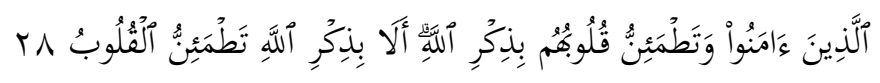

(yaitu) orang-orang yang beriman dan hati mereka manjadi tenteram dengan mengingat Allah. Ingatlah, hanya dengan mengingati Allah-lah hati menjadi tenteram (QS. Ar-Ra'd [13]: 28) ${ }^{5}$

Dalam konteks pelaksanaan zikir, manusia memiliki resepsi yang menarik untuk dikaji. Guna untuk memperoleh informasi mengenai pelaksanaan zikir di kalangan masyarakat yang tidak hanya sebatas sebagai pelaksanaan ubudiyah, namun ada juga yang meresepsi bahwa dengan pembacaan zikir mampu mendatangakan kekuatan magis atau pengobatan dan tujuan-tujuan lainnya.

Di antara ekspresi hasil interaksi manusia dengan zikir adalah munculnya ragam variasi dalam pelaksanaannya, salah satunya ialah terbentuknya majlis zikir Al-Khidmah yang rutin menggunakan manaqib sebagai zikir. Tradisi membaca manaqib biasanya dilakukan oleh warga nahdliyin -warga yang berpaham ahlusunnah wa al-jamaah- untuk acara-acara/hajatan khusus, seperti majlis tahlil, lamaran, akad nikah, walimatu al-ursy -resepsian, walimatu al-haml-tujuh bulanan, walimatu altasmiyah - pemberian nama anak, haul, dan miladiyah -ulang tahun/hari jadi. Menariknya dalam setiap majlis zikir tersebut mayoritas jamaah majlis zikir manaqib dan warga sekitar acara membawa wadah - biasanya berupa botol- yang sudah di isi air putih. Wadah tersebut kemudian dibuka dan diletakan di sekitar dirinya atau kiyai-kiyai yang hadir dalam majlis tersebut.

\footnotetext{
${ }^{2}$ Eko Sulistyo Kusumo, "Bentuk Sinkretisme Islam-Jawa Di Masjid Sunan Ampel Surabaya,” Jurnal Mozaik Vol. 15, No. 1 (2015): hlm. 1-13.

${ }^{3}$ Clifford Greetz, Kebudayaan Dan Agama (Yogyakarta: Kansius, 1992), hlm. 2-3.

${ }^{4}$ Fahrurozi Dahlan, Tuan Guru: Eksistensi Dan Tantangan Peran Dalam Transformasi Masyarakat (Jakarta: Sanabil, 2015), hlm. 24.

${ }^{5}$ Yayasan Penyelengga/Penafsir Al-Qur'an Departemen Agama Republik Indonesia, Alhidayah; Al-Qur'an Tafsir Per Kata Tajwid Dan Kode Angka (Tanggerang Selatan: Kalim, n.d.), hlm. 253.
} 
Sebelumnya, telah dilakukan penelitian mengenai pembacaan manaqib majlis zikir AlKhidmah. Saiful Amri misalnya, penelitiannya yang berjudul "Peran Manaqib Syaikh Abdul Qadir Aljilani dalam Meningkatkan Spiritualitas Santri Pondok Pesantren Assalafi Al Fithrah Meteseh," berupaya menjelaskan tentang bagaimana efek manaqib dalam kehidupan keseharian santri; ada yang merasa tenang, juga ada yang merasa tentram. ${ }^{6}$ Penelitian serupa juga dilakukan oleh Lailatul Jannah yang berjudul "Peran Majelis Dzikir Al Khidmah dalam Mengembangkan Kecerdasan Spiritual (Studi pada Jamaah Majelis Dzikir Mahasiswa Al Khidmah Kota Salatiga 2016).” Dalam penelitiannya ini, Jannah menjelaskan bahwa majlis manaqib bisa menenangkan jiwa dan menentramkan hati, meningkatkan silaturrahim, menimbulkan kesadaran beragama yang semakin kuat, memfungsikan hati untuk lebih taat kepada Allah SWT, serta mengembalikan segala persoalan hidup hanya kepada Allah SWT. ${ }^{7}$

Kedua penelitian di atas belum menyinggung masalah resepsi masyarakat tentang air yang dibacakan manaqib. Artinya, kedua penelitian di atas masih membicarakan dampak kegiatan pembacaan manaqib secara untuk meningkatkan pengembangan diri. Oleh karena itu, kajian tersebut belum menyentuh pada tataran konstruksi pemahaman masyarakat dalam pembahasan mengenai benda-benda yang terkait dengan pembacaan manaqib.

Berangkat dari latarbelakang di atas, penulis tertarik mengkaji bagaimana konstruksi pemahaman jamaah majlis zikir Al-Khidmah tentang fungsi manaqib dan motivasi apa yang mempengaruhi dan menggerakan jamaah majlis zikir Al-Khidmah untuk meletakkan air di sekitar tempat pembacaan manaqib.

\section{B. Metode Penelitian}

Berdasarkan fenomena masalah yang telah ditentukan, maka peneliti menggukan metode kualitatif dalam melakukan penelitian. Menurut Bogdan dan Taylor (1975) dalam Moeloeng (2015), mendefinisikan metodologi kualitatif sebagai prosedur penelitian yang menghasilkan data deskriptif berupa kata-kata tertulis atau lisan dari orang-orang dan perilaku yang diamati. Menurut mereka, pendekatan ini diarahkan pada latar dan individu tersebut secara holistik (utuh). ${ }^{8}$ Jadi dalam hal ini tidak boleh mengisolasi individu atau organisasi ke dalam variabel atau hipotesis, tetapi perlu memandangnya sebagai bagian dari suatu kebutuhan. Jenis penelitian ini adalah penelitian fenomenologi. ${ }^{9}$ Pengumpulan data menggunakan observasi dan wawancara. ${ }^{10}$ Oleh karena itu, data primer dalam kajian ini meliputi aspek sosial dan nilai pada acara majlis zikir Al-Khidmah berpusat di Pondok Pesantren Al-Salafi Al-Fithrah Kenjeran Surabaya. Kemudaian ditopang dengan sumbersumber sekunder yang meliputi kajian-kajian tasawuf dan keislaman. Setelah semua data terkumpul, akan dianalisis menggunakan teori Peter L. Berger dan Thomas Luckman yang meliputi subjective reality, symbolic reality, dan objective reality. Setelah itu tentang eksternalisasi, objektifikasi, dan internalisasi. ${ }^{11}$

${ }^{6}$ Saiful Amri, "Peran Manaqib Syaikh Abdul Qadir Aljilani Dalam Meningkatkan Spiritualitas Santri Pondok Pesantren Assalafi Al Fithrah Meteseh" (Skripsi, Semarang, Fakultas Ushuluddin dan Humaniora UIN Walisongo, 2018).

${ }^{7}$ Lailatul Jannah, "Peran Majelis Dzikir Al Khidmah Dalam Mengembangkan Kecerdasan Spiritual (Studi Pada Jamaah Majelis Dzikir Mahasiswa Al Khidmah Kota Salatiga 2016)" (Skripsi, Salatiga, Fakultas Tarbiyah dan Ilmu Keguruan IAIN Salatiga, 2017).

${ }^{8}$ Lexy. J. Moleong, Metode Peneltian Kualitatif (Bandung: Remaja Rosdakarya, 2015), hlm. 4.

${ }^{9}$ Nana Syaodih Sukmadinata, Metode Penelitian (Bandung: Remaja Rosdakarya, 2015), hlm. 72.

${ }^{10}$ Sutrisno Hadi, Metodologi Research II (Yogyakarta: Andi Offset, 2011), hlm. 136.

${ }^{11}$ Peter L. Berger dan Thomas Luckmann, The Social Construction of Reality (London: Penguin Books, 1991). 


\section{Pembahasan atau Analisis}

\section{Mengenal Majlis Zikir Al-Khidmah}

Al-Khidmah merupakan sebuah jam'iyah/majlis zikir yang didirikan oleh KH. Achmad Asrori bin Oetsman Al-Ishaqy sejak tahun 1987. Majlis ini berpusat di Pondok Pesantren Al-Salafi Al-Fithrah Jl. Kedinding Lor 99, kelurahan Tanah Kali Kedinding, kecamatan Kenjeran Surabaya. Majlis zikir Al-Khidmah resmi dibentuk kepengurusan semenjak munas dan acara halal bi halal di Semarang pada tahun 2005, lebih tepatnya pada tanggal 23 Desember 2005. ${ }^{12}$

Jauh sebelum Al-Khidmah dibentuk, yakni sekitar tahun 1980-an, Kiai Asrori muda sering bergaul dengan pemuda dikota Gresik. Pertama kali, pemuda yang didekati oleh Kiai Asori bernama Syamsul Hadi yang memiliki julukan "Puyuh." Pemuda ini menamai dirinya sebagai seorang seniman jalanan -anak embongan- dan sering mangkal di Terminal Bunder kota Gresik. Tidak ada hari belang bagi Puyuh untuk tidak meneguk minuman keras dan sebagainya. Kehadiran Kiai Asrori memberikan efek yang positif untuk pribadi Puyuh, akhirnya bertaubat dan mengikuti laku Kiai Asrori. Puyuh berhasil mengumpulkan lima belas (15) orang temannya untuk sama-sama membuat kegiatan zikir dengan tujuan mendekatkan diri kepada Allah SWT. Akhirnya gayung bersambut, sampai kemudian dari 15 orang tersebut menjadi 500 orang pemuda. Kiai Asrori memberikan nama perkumpulan pemuda tersebut dengan nama Orong-orong -hewan sejenis jangkrik yang berbentuk kecil dan muncul di waktu malam yang selalu mencari cahaya terang untuk dikelilinginya. ${ }^{13}$

Jamaah Al-Khidmah terbentuk seiring bertambahnya murid beliau -KH. Asrori- yang memerlukan pembinaan. Banyaknya murid yang berbaiat di thariqat Qadariyah wa Naqsabandiyah al-Utsmaniyah tersebut tersebar di berbagai daerah. Timbullah keresahan dan kekhawatiran dari sang guru atas pembinaan yang kurang termonitor. ${ }^{14}$ Sekali lagi, dengan begitu, dibentuklah Jamaah Al-Khidmah ini.

Awal kata Al-Khidmah muncul, ketika para santri mengirimkan surat undangan yang ditujukan untuk masyarakat sekitar, di bagian pojok undangan tersebut ditulis kata "Al-Khidmah" yang berarti pelayan/melayani. Lambat laun masyarakat sekitar menyebut majlis zikir yang diselenggarakan oleh jamaah di Pondok Pesantren Al-Fithrah dengan nama Majlis Zikir AlKhidmah. Dan, nama itu sampai sekarang masih bertengger dipergunakan.

Jamaah Al-Khidmah memiliki visi sebagai berikut;

"Mewujudkan generasi yang shalih shalihah sejahtera lahir dan batin, yang pandai bersyukur, dapat menyenangkan hati keluarganya, orang tuanya, guru-gurunya, hingga Nabi Besar Muhammad SAW sesuai dengan petunjuk Alquran dan hadis serta tuntunan ahklak para Salafuna as-Shalih."

Visi tersebut dijalankan dalam misi Al-Khidmah sebagai berikut; pertama, mewujudkan keluarga yang shalih shalihah sejahtera lahir dan batin, yang senang berkumpul dalam majelis zikir, maulid, dan manaqib serta kirim doa kepada orang tua. Kedua, mewujudkan masyarakat yang shalih shalihah sejahtera lahir dan batin, yang senang berkumpul dalam majelis zikir, maulid, dan manaqib serta kirim doa kepada orang tua. Ketiga, mewujudkan pejabat yang shalih shalihah sejahtera lahir dan batin, yang senang berkumpul dalam majelis zikir, maulid, dan manaqib serta

${ }^{12}$ Ahmad Asrori Al-Ishaqy, Pedoman Kepemimpinan Dan Kepengurusan Dalam Kegiatan Dan Amaliyah AthThariqoh Dan Al Khidmah, Cet. Ke-VIII (Surabaya: Pengurus Pusat Al Khidmah, 2017).

${ }^{13}$ Hasil wawancara, dengan Kiai Nur Salim -salah satu imam Khususi di Lamongan, 26 Juli, 2020.

${ }^{14}$ Hasil wawancara, dengan Kiai Nur Salim -salah satu imam Khususi di Lamongan. 
kirim doa kepada orang tua. Keempat, mewujudkan jamaah yang shalih shalihah sejahtera lahir dan batin, yang senang berkumpul dalam majelis zikir, maulid, dan manaqib serta kirim doa kepada orang tua. Kelima, mewujudkan pengurus yang shalih shalihah sejahtera lahir dan batin, yang senang berkumpul dalam majelis zikir, maulid, dan manaqib serta kirim doa kepada orang tua. Keenam, mewujudkan usaha-usaha yang dapat meningkatkan kesejahteraan masyarakat, sehingga lebih istikamah beribadah. ${ }^{15}$

Berikut lambang majlis zikir Al-Khidmah;

Gambar 1: lambang/simbol majlis zikir Al-Khidmah ${ }^{16}$

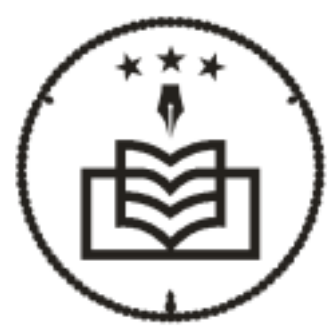

Gambar di atas memiliki makna: pertama, pena sebagai perlambang terus belajar; kedua, pena menghadap kebawah sebagai pertanda mencari ilmu sejak lahir sampai meninggal; ketiga, empat buah kitab menggambarkan bahwa semua keputusan merujuk kepada Alquran, hadis, ijma', dan qiyas; keempat, tiga buah bintang merupakan lambang iman, Islam, dan ihsan; kelima, tasbih perlambang mengikuti ulama terdahulu -salafuna as-shalih; keenam, pentolan tasbih mengarah ke dalam pertanda kesungguhan dan keikhlasan mengabdi kepada Allah SWT; ketujuh, pentolan tasbih yang panjang di bawah dan menghadap atas, perlambang rendah hati, mawas diri, kearifan demi meraih rahmat Allah SWT. ${ }^{17}$

Dari waktu ke waktu majlis zikir Al-Khidmah mengalami kemajuan yang pesat, tidak hanya di Indonesia, melainkan di beberapa penjuru dunia, di antaranya; Malaysia, Thailand, Singapura, Arab Saudi, Brunai Darussalam, dan lain-lain. Majlis zikir Al-Khidmah tidak hanya diselenggarakan oleh masyarakat sipil, melainkan menembus institusi-institusi pemerintahan, misalkan hari jadi kotakota/kabupaten besar di Indonesia. Dalam perkembangannya juga Al-Khidmah juga merambah di kampus-kampus besar yang diberi nama Mahasiswa Al-Khidmah. Mahasiswa Al-Khidmah sendiri sudah berada di kurang lebih sembilan puluh tiga (93) Perguruan Tinggi di Indonesia, seperti UI, UII, UIN, UNPAD, UNNES, ITS, ITB, dan lain-lain. Tidak hanya Perguruan Tinggi di Indonesia, ada juga beberapa Perguruan Tinggi di Malaysia, Singapura, Bruna Darussalam, dan lain-lain. ${ }^{18}$

\section{Manaqib: Antara Biografi dan Amaliyah}

Kata manaqib mempunyai padanan -sinonim/muradlif- dengan kata sejarah, tarikh, biografi, kisah, dan hikayat. Secara bahasa manaqib -manakib- berarti kisah kekeramatan para wali. ${ }^{19}$ Sedangkan secara istilah manaqib ialah cerita kekeramatan para wali yang dapat didengar dari juru kunci makam, dari keluarga dan muridnya, atau dibaca dalam sejarah-sejarah. ${ }^{20}$ Pengertian berbeda diutarakan oleh KH. Achmad Asrori, bahwa manaqib ialah perilaku terpuji di sisi Allah SWT. yang

${ }^{15}$ Al-Ishaqy, Pedoman Kepemimpinan Dan Kepengurusan Dalam Kegiatan Dan Amaliyah Ath- Thariqoh Dan Al Khidmah.

${ }^{16} \mathrm{https}$ ://alfithrah99sby.org/lambang-pondok/ diakses pada tanggal 01 Agustus 2020.

${ }^{17} \mathrm{https}$ ://alfithrah99sby.org/lambang-pondok/ diakses pada tanggal 01 Agustus 2020.

18 Afif Hasbullah, "Menggagas Kehadiran Al Khidmah Di Kampus Sebagai Salah Satu Strategi Bela Negara; Pengalaman Di Unisda Lamongan," https://afifhasbullah.com/ diakses pada 2 Agustus 2020.

${ }^{19}$ https://kbbi.kemdikbud.go.id/entri/manakib.

${ }^{20}$ Abu Bakar Aceh, Pengantar Sejarah Sufi Dan Tasawuf (Solo: Romadhoni, 1990), hlm. 355. 
diketahui oleh banyak orang tentang suatu sosok, ia mempunyai sifat yang menarik lagi manis, pembawaan etika yang baik nan indah, kepribadian yang bersih, suci lagi luhur, kesempurnaan yang tinggi dan agung, serta karomah yang agung di sisi Allah SWT. ${ }^{21}$

Genealogi manaqib berasal dari bahasa Arab "naqaba-yanqubu-naqban," yang memiliki arti mengebor, menggurdi, menembus, memeriksa, dan menggali. Kata manaqib adalah jama' -pluraldari lafadz "manqibun" yang merupakan bentuk isim makan. ${ }^{22}$ Dalam Alquran lafadz naqaba disebut tiga kali dengan berbagai bentuk. ${ }^{23}$ Dalam QS. Al-Maidah (5): 12 disebutkan dengan lafadz "naqiiban" yang berarti pemimpin. Kemudian dalam QS. Al-Kahfi (18): 97 disebutkan dengan lafadz "naqban" yang berarti menolong/melubangi. Terakhir dalam QS. Qaf (50): 36 disebutkan dengan lafadz "naqqabuu” yang berarti menjelajah.

Dari ketiga ayat di atas ternyata ada kesesuian dengan lafadz naqaba, yakni pemimpin, menolong, dan menjelajah; menjelajah sebagai awal munculnya manaqib; pimpinan yang bisa dijadikan suri tauladan; dan menolong yang sejalan dengan tujuan diadakannya manaqib, yakni mendapatkan berkah untuk datangnya pertolongan Allah SWT. Dapat disimpulkan bahwa manaqib ialah riwayat hidup yang berhubungan dengan seorang tokoh masyarakat yang dijadikan suri tauladan, baik silsilah, akhlak, keramahan, dan lain sebagainya.

Dalam perkembangan selanjutnya, kata manaqib -bagi sebagian besar warga nahdliyinmerujuk kepada buku yang mengisahkan perjalanan hidup Syeikh Abdul Qadir Al-Jilani ra. -ulama kelahiran Iraq tahun $471 \mathrm{M}$, dengan berbagai karamah dan petuah filosofinya. ${ }^{24}$ Ia bernama lengkap Abdul Qadir bin Abu Shalih Musa Janki Dausat bin Abu Abdullah bin Yahya Az-Zahid bin Muhammad bin Dawud bin Musa bin Abdullah bin Musa Al-Jun bin Abdullah Al-Mahadh. ${ }^{25}$ Ia juga dikenal sebagai Syaikh Muhyiddin Abu Muhammad Abdul Qadir bin Abu Saleh Jinki Dusat bin Musa Al-Juun bin Abdullah Al-Mahdh bin Hasan Al-Mutsanna bin Amirul Mu'minin Abu Hasan bin Amirul Mu'minin Ali bin Abi Thalin bin Abdul Muthalib bin Hasyim bin Abdul Manaf bin Qushay bin Kilab bin Murrah bin Ka'ab bin Luay bin Ghalib bin Fahr bin Malik bin Nadhar bin Kinanah bin Khuzaimah bin Mudrikah bin Ilyas bin Madhar bin Nadzaar bin Ma'ad bin Adnan AlQurasyi Al-Alawi Al-Hasani Al-Jiili Al-Hambali. ${ }^{26}$

Manaqib muncul di Indonesia seiring tersebarnya tasawuf di Indonesia. Sebab ajaran tasawuf memunculkan berbagai amalan dalam Islam. Seperti thariqah yang berkembang memunculkan amalan manaqib ini. Ketika pedagang muslim mengislamkan masyarakat Indonesia, tidak hanya menggunkan pendekatan bisnis namun juga menggunakan pendekatan tasawuf. ${ }^{27}$ Demikian pula awal penyebaran Islam di pulau Jawa, para ulama yang dipimpin oleh wali sanga telah mengajarkan kepada masyarakat Islam tentang ilmu thariqah, manaqib, dan amalan lain yang selaras dengan itu. Praktik tersebut digunakan sebagai sarana dakwah penyebaran Islam sampai sekarang. ${ }^{28}$ Dengan demikian dapat disimpulkan bahwa timbulnya manaqib sejalan dengan ulama yang menyebarkan Islam di Indonesia yang dipimpin oleh para sufi.

\footnotetext{
${ }^{21}$ Achmad Asrori Al-Ishaqy, Apa Manaqib Itu? (Surabaya: Al-Wafa, 2010), hlm. 9.

${ }^{22}$ Habib Abdullah Zaqy Al-Kaaf, Manaqib Syekh Abdul Qodir Al-Jailani: Perjalanan Spiritual Sulthonul Auliya' (Bandung: Pustaka Setia, 2004), hlm. 59.

23 Muhammad Ainul Yaqin, "Dzikir Manaqib: Moderasi Islam Di Tengah Masyarakat Multikultural," Proceedings 2nd Annual Conference for Muslim Scholars Kopertais Wilayah IV Surabaya, April 21, 2018, hlm. 951.

${ }^{24}$ Abiel wafa Iie 'Izzati Maulana Al Jalily, MP3 (Manaqib Philoshofi Islami Penyegar Iman Penyejuk Qolbu) (Mranggen: Daru Tashfiyyah Eqolbi, 2014), hlm. 7.

${ }^{25}$ Said bin Musfir Al-Qahthani, Syaikh Abdul Qadir Al-Jailani (Jakarta: Darul Falah, 2005), hlm. 13.

${ }^{26}$ Syaikh Muhammad bin Yahya At-Tadafi, Syaikh Abdul Qadir Al-Jailani Mahkota Para Aulia Kemuliaan Hamba Yang Ditampakkan-Nya (Jakarta: Prenada Media, 2005), hlm. 1.

${ }^{27}$ Mahjudin, Kuliah Akhlak Tasawuf (Jakarta: Kalam Mulia, 1991), hlm. 93.

${ }^{28}$ Imron Abu Umar, Kitab Manaqib Tidak Merusak Aqidah Islamiyyah (Kudus: Menara Kudus, 1989), hlm. 11.
} 
Tradisi membaca manaqib biasanya dilakukan oleh warga nahdliyin -warga yang berpaham ahlusunnah wa al-jamaah- untuk acara-acara/hajatan khusus, seperti majlis tahlil, lamaran, akad nikah, walimatu al-ursy -resepsian, walimatu al-haml -tujuh bulanan, walimatu al-tasmiyah pemberian nama anak, haul, dan miladiyah - ulang tahun/hari jadi.

Tradisi/amaliyah yang dilaksanakan dalam majlis zikir Al-Khidmah sesuai dengan standar urutan majlis yang telah diamalkan oleh Hadratus Syaikh KH. Achmad Asrori Al-Ishaqy ra. yaitu; pertama, tawasul, yaitu pembacaan fatihah yang dipimpin oleh Imam Khususi atau Kyai atau Habaib untuk arwah-arwah auliya' dan orang shalih. Kedua, istighotsah, yaitu membaca kalimah tayyibah. Ketiga, pembacaan Surat Yaasin. Keempat, pembacaan doa Yaasin dibacakan oleh Imam Khususi atau Kyai atau habaib. Kelima, pembacaan manaqib yang dibacakan oleh 7 pembaca sesuai dengan bab manaqib yang ada. Keenam, pembacaan doa manaqib dibacakan oleh Imam Khususi atau Kyai atau Habaib. Ketujuh, pembacaan tahlil sesuai dengan bacaan tahlil yang ada di kitab "Al Faidhu Rohmaniyah" atau kitab "Iklil" yang dikarang oleh Hadratus Syaikh KH. Achmad Asrori AlIshaqy ra. Kedelapan, pembacaan doa tahlil. Kesembilan, pembacaan selawat "Ibadallah." Kesepuluh, pembacaan selawat "Yaa Arhamar Roohimin." Kesebelas, zikir "Laa Ilaaha Illa Allah" bersama diiringi dengan kasidah. Keduabelas, pembacaan maulidurrasul SAW. Dan terakhir, penutup doa maulidurrasul.

\section{Konstruksi Pemahaman tentang Banyu Manaqib}

Tradisi meletakkan air dalam sebuah acara keagamaan telah berlangsung lama dan tidak hanya terjadi di majlis zikir Al-Khidmah; taruhlah misal pada semaan Alquran Jantiko Manteb, ${ }^{29}$ kemudian di acara muludan di masjid Sunan Ampel Surabaya, ${ }^{30}$ ada juga tradisi semaan Alquran pada haul Akbar di Pondok Pesantren Zainul Hasan Genggong Probolinggo ${ }^{31}$, juga di Pondok Pesantren Matholi'ul Anwar Lamongan. ${ }^{32}$

Akar dari tradisi ini mengarah kepada air yang didoakan. Hal ini sesuai dengan penelitian yang dilakukan oleh Benny Johanson, peneliti asal Swedia. Dalam artikelnya yang diterbitkan oleh "Internal Medicine Review," Johansen menuturkan bahwa air dapat memberikan manfaat untuk kesehatan fisik dan psikis. ${ }^{33}$ Sebelumnya, ada juga peneliti asal Jepang bernama Masaru Emoto, ia melakukan penelitian tentang air yang mengandung molekul positif ketika didekatkan dengan katakata yang positif. ${ }^{34}$ Kalau yang dibaca dalam majlis zikir adalah doa-doa atau kebaikan, maka hal demikian bisa dibuktikan secara ilmiah tidak serta merta hanya implikasi dari sugesti.

Mengarah kepada air yang didoakan, penyebutan banyu manaqib memiliki padanan yang beragam, ada yang mengenal dengan istilah banyu bening - air putih, banyu asma', banyu buthek air keruh, banyu rajah, dan banyu barokah. Meski penyebutan tersebut dengan berbagai macam, namun secara esensial memiliki kesamaan, yakni sama-sama mempunyai "nilai" lebih yang sering digunakan sebagai obat atau hal lain, seperti pelaris dagangan.

${ }^{29}$ Wahyudi dan Muhammad Zaini, "Pemahaman Jama'ah Sema'an Al-Qur'an Jantiko Mantab Tentang Banyu Barokah," Ibda': Jurnal Kajian Islam Dan Budaya Vol. 18, No. 1 (2020): hlm. 31-47, https://doi.org/DOI: 10.24090/IBDA.V18i1.3536.

${ }^{30}$ Eko Sulistyo Kusumo, "Bentuk Sinkretisme Islam-Jawa Di Masjid Sunan Ampel Surabaya,” hlm. 1-13.

31 Wawancara dengan Najwan Nada, ustazah di Pondok Pesantren Zainul Hasan Genggong dengan menggunakan Via whatsapp, pada 01 Agustus 2020.

${ }^{32}$ Wawancara dengan M. Fathihul Anwar, ustadz di Pondok Pesantren Matholi'ul Anwar Lamongan dengan menggunakan Via Whatsapp, pada 01 Agustus 2020.

${ }^{33}$ Benny Johansson, "Functional Water-In Promotion of Health Beneficial Effects and Prevention of Disease," Internal Medicine Review Vol. 3, No. 3 (2016): hlm. 1-24.

34 A.S. Hamidin, Kebaikan Air Putih (Terapi Air Untuk Penyembuhan, Diet, Kehamilan Dan Kecantikan) (Yogyakarta: Media Pressindo, 2010), hlm. 15. 
Secara esensi memang ada kesamaan dalam air yang terkandung di dalamnya, namun terdapat perbedaan dalam penyajian. Fathoyah menuturkan bahwa banyu bening dan banyu asma' ialah air yang hanya diberikan doa saja secara khusus sesuai dengan permintaan atau hajat yang bersangkutan tanpa ada campuran apapun. Banyu buthek ialah air putih yang diberikan doa atau mantra khusus sesuai dengan permintaan yang bersangkutan dan kadang dikasih campuran garam, kembang, dan/atau lain sebagainya. Banyu rajah ialah air putih yang di dalamnya diberikan potongan kertas yang sudah ditulis wifiq/rajah. ${ }^{35}$ Banyu barokah ialah air yang diletakkan di tengahtengah bacaan semaan Alquran. ${ }^{36}$ Sedangkan yang dimaksud banyu manaqib dalam artikel ini ialah air yang diletakkan di tengah-tengan prosesi pembacaan manaqib dalam rangkaian majlis zikir AlKhidmah.

Dalam konsepsi masyarakat yang mengikuti majlis zikir Al-Khidmah, banyu manaqib mempunyai berbagai fungsi dan manfaat. Nur Salim mengatakan, bahwa air yang dibacakan manaqib dapat digunakan sebagai media pengobatan penyakit. Hal ini sejalan dengan profesi kesehariannya sebagai kiai yang dipercaya oleh banyak orang bisa menyembuhkan banyak penyakit. Lebih lanjut Nur Salim mengatakan;

“.....tidak hanya menyembuhkan penyakit, saya juga menggunakan air itu untuk segala keluhan dari yang minta (pasien). Mulai dari menyapih anak, penglaris dagangan, pengasihan, tangkis rumah, dan masih banyak lagi.,"37

Hal serupa juga diungkapkan oleh Kasmadi, namun dalam praktek keseharian, Kasmadi menggunakan banyu manaqib lebih ke arah prefentif, yakni sebagai alat pencegahan. Ia memasukkan banyu manaqib -yang ia peroleh dari acara majlis zikir- ke dalam wadah yang mempunyai kapasitas lebih banyak, seperti gentong tempat penyimpanan air. Melalui media ini Kasmadi dan keluarga berniat meminta perlindungan kepada Allah SWT. dari segala penyakit dan marabahaya. ${ }^{38}$

Ada juga yang mengatakan bahwa air manaqib mempunyai khasiat untuk menambah kecerdasan. Khoiriyatul Ma'wa menegaskan bahwa hal tersebut sering ia lakukan jika selesai mengikuti majlis zikir Al-Khidmah air yang ia peroleh secara khusus diberikan kepada anakanaknya yang masih sekolah agar dalam proses belajar mendapatkan kemudahan dan keberkahan. ${ }^{39}$ Hal serupa juga diamini oleh jamaah mahasiswa Al-Khidmah, terkhusus di UIN Sunan Ampel Surabaya. Singgih mengatakan bahwa dalam banyu manaqib tersebut, ia percaya jika diminum terdapat ketenangan dan kelapangan hati dalam menjalankan proses perkuliahan. ${ }^{40}$

Sedangkan Nuriyati mempercayai bahwa nilai yang terkandung dalam banyu manaqib dapat membuat hati menjadi tenang, terhindar dari sifat hasud, dengki, iri, dan sebagai pembersih sifatsifat tercela lainnya. ${ }^{41}$ Akhirnya kehidupan ini menjadi berkesan dan diselimuti keberkahan, segala persoalan akan cepat dihilangkan oleh Allah SWT. dan selalu dimudahkan dalam menjalankan aktivitas.

\footnotetext{
${ }^{35}$ Wawancara dengan ibu Fathoyah, salah seorang dukun Jawa, pada tanggal 30 Juli, 2020.

${ }^{36}$ Wahyudi dan Muhammad Zaini, "Pemahaman Jama'ah Sema'an Al-Qur'an Jantiko Mantab Tentang Banyu Barokah." 31-47.

${ }^{37}$ Wawancara dengan Kiai Nur Salim, ia adalah seorang kikun, istilah Jawa bagi kiai yang juga merapal sebagai dukun, pada tanggal 26 Juli, 2020.

${ }^{38}$ Wawancara dengan Kasmadi, jamaah majlis zikir Al-Khidmah, pada tanggal 28 Juli, 2020.

${ }^{39}$ Wawancara dengan Khoiriyatul Ma’wa, jamaah majlis zikir Al-Khidmah, pada tanggal 26 Juli, 2020.

${ }^{40}$ Wawancara dengan Singgih Pratama, aktivis Mahasiswa Al-Khidmah UIN Sunan Ampel Surabaya, dengan menggunakan Via whatsapp, pada tanggal 31 Juli, 2020.

${ }^{41}$ Wawancara dengan Nuriyati, jamaah majlis zikir Al-Khidmah, pada tanggal 29 Juli, 2020.
} 
Di kalangan NU, tradisi seperti ini sudah menjadi lauk pauk -terbiasa- dalam keseharian. Sulit untuk melacak akar sejarah kapan tradisi ini berawal. Selanjutnya, jika ditelisik dari cara penyajian dan media yang digunakan dalam banyu manaqib, sejak dahulu masyarakat Indonesia -terkhusus masyarakat Jawa, mengenal istilah suwuk. Suwuk ialah tiupan dari seorang dukun dengan membaca mantra-mantra khusus, dengan niatan khusus sesuai dengan permintaan yang berkepentingan, mulai dari pengobatan sampai pengasihan. ${ }^{42}$

Sekilas jika diteliti, penyajian banyu manaqib persis dengan dengan penyajian banyu barokah dan suwuk. Perbedaannya, rapalan doa yang dibacakan dalam banyu barokah menggunakan ayatayat Alquran dari awal sampai khatam, sedangkan dalam suwuk, dibacakan mantra yang sesuai dengan kebutuhan tamu atau pasien dan disertai dengan "lelaku" tertentu yang telah dipelajari oleh sang dukun.

Sebenarnya semua orang bisa melakukan suwuk, namun tidak bisa dipastikan kemujarabannya. Oleh karena itu orang Jawa mengenal istilah suwuk mandi dan suwuk ora mandimujarab dan tidak mujarab. ${ }^{43}$ Patokan dukun dikatakan mandi ialah, ketika banyak permintaan tamu yang terwujudkan lantaran pertolongan Allah melalui dia -sang dukun. Namun tak jarang ada yang mengartikan istilah mandi dengan lebih sederhana, yakni bisa dilihat dari banyaknya tamu atau pasien yang antri karena kesaktian sang dukun. Masyarakat Jawa percaya jika ada empat puluh orang berdoa bersama, kekuatan doa tersebut menyerupahi doa satu wali. Untuk meminimalisir keora mandi-an tersebut, dibentuklah halaqah-halaqah untuk berdoa bersama yang kemudian muncul istilah manaqiban, tahlilan, yasinan, dan lain sebagainya. Dari situlah secara terminologis banyu manaqib berasal, yakni dari gabungan dua term banyu dan manaqib. Adapun banyu dalam bahasa Jawa berarti air, sedang manaqib merujuk pada sebuah ritual keagamaan pembacaan biografi Syeikh Abdul Qodir Al-Jilani ra. secara berjamaah. Jadi banyu manaqib ialah air yang dbacakan manaqib Syeikh Abdul Qodir Al-Jilani ra. secara bersama-sama.

Realitas di atas memberikan gambaran adanya keterkaitan antara budaya dengan agama. Jika merujuk pada aspek histori tersebut, adanya tradisi banyu manaqib merupakan kreasi dari budaya suwuk sejak zaman dahulu yang telah mengakar di nusantara. Relasi agama dan budaya tersebut bisa berupa asimilasi dan akulturasi. Ketika kedua budaya tersebut saling terbuka dan memiliki titik persinggungan yang relatif lama maka akan menimbulkan kebudayaan baru dengan tidak menghilangkan identitas yang lama.

Namun akhir-akhir ini tradisi di atas mendapat banyak penolakan, umumnya kelompokkelompok Islam kiri. ${ }^{44}$ Padahal praktek penyembuhan penyakit atau mencari keberkahan untuk kesembuahan penyakit sudah ada sejak generasi awal. Ummu Salamah -sahabat Nabi- mengambil rambut Nabi SAW. untuk dimasukkan dalam air kemudian diminumkan kepada orang-orang yang sakit. Ia berkeyakinan bahwa terdapat keberkahan dalam rambut Nabi SAW. dan terdapat nilai yang bisa menyembuhkan. ${ }^{45}$ Ummu Salamah ini berawal dari hadits yang menceritakan bahwa Nabi SAW. menyuruh sahabat Anas untuk menyampaikan rambut sisi kanan beliau kepada ibunya Ummu Sulaim istri Abu Thalhah- yang sedang sakit. Anas bercerita waktu itu Rasulullah SAW. memotong rambut sisi kanannya di Mina dengan dipegang tangan kanan beliau sendiri, selesai mencukur beliau menyerahkannya kepada Anas untuk disampaikan kepada Ummu Sulaim, ibunya.

\footnotetext{
42 Novia Luthviatin, "Mantra Untuk Penyembuhan Dalam Tradisi Suku Osing Banyuwangi,” Jurnal Ikesma Vol. 11, No. 1 (2015): hlm. 36-39.

43 Ali Nurdin, "Komunikasi Magis Dukun (Studi Fenomenologi Tentang Kompetensi Komunikasi Dukun)," Jurnal Komunikasi Vol. 1, No. 5 (2012): hlm. 389.

44 Amin Farih, "Paradigma Pemikiran Tawasul Dan Tabarruk Sayyid Ahmad Ibn Zaini Dahlan Di Tengah Mayoritas Teologi Mazhab Wahabi," Jurnal Theologia Vol. 27, No. 2 (2016).

${ }^{45}$ Ibn Hajar al-Atsqalani, Sharh Al-Bukhari Fath al-Bari Li Ibni Hajar, juz 10, n.d., hlm. 290.
} 
Karena kejadian itu, sahabat yang lain memungut sisa rambut Rasulullah SAW. yang sebelah kiri, termasuk golongan sahabat yang memungut rambut tersebut ialah Ummu Salamah. Selain itu, terdapat juga cerita bahwasanya sahabat Abi Usaid mengambil berkah dan meminta kesembuhan penyakit dari sumur yang diludahi Nabi SAW. yang diberi nama Sumur Buda'ah. Dalam riwayat yang diceritakan oleh Abu Hamzah ibn Abi Usaid al-Sa'di al-Khazraji dari ayahnya dari kekeknya bahwasanya Abu Usaid memiliki sumur yang diberi nama Sumur Buda'ah yang telah diludai oleh Rasulullah SAW. barang siapa yang minum dari air sumur itu akan bertambah kewibawaan dan disembuhkan dari banyak penyakit. ${ }^{46}$

Dua cerita di atas membuktikan bahwa memakai sesuatu sebagai lantaran meminta kesembuhan penyakit dan meminta keberkahan hidup sudah ada sejak zaman Nabi SAW.. Dua cerita tadi juga menyatakan bahwa media yang digunakan sebagai "alat transfer" adalah air, sama seperti yang dilakukan oleh jamaah majlis zikir Al-Khidmah yang menggunakan air sebagai media banyu manaqib, meski inang -sumber- nya berbeda. Ummu Salamah menggunakan rambut, Abi Usaid menggunakan ludah, dan jamaah majlis zikir Al-Khidmah menggunakan manaqib.

Dalam penelitian yang dilakukan oleh Masaru Emoto, air merupakan materi yang memberikan respon terhadap kata-kata. Jika kata yang didekatkan positif maka air akan mengkristal menjadi bungah air, jika kata yang didekatkan negatif maka air akan pecah tak beraturan. Kata-kata ini berlaku baik secara lisan dan/atau tulisan. Termasuk juga berlaku bagi air yang terdapat dalam tubuh manusia sebagai penyembuhan berbagai macam penyakit. ${ }^{47}$ Karena sifatnya yang mudah larut dalam tubuh dan sensitif terhadap kata-kata ${ }^{48}$, maka air cocok digunakan sebagai media transfer banyu manaqib jamaah majlis zikir Al-Khidmah.

Lebih lanjut jika ditinjau dalam segi konstruksi sosial menurut Berger dan Luckman bahwa institusi manusia dipertahankan dan dibentuk berdasarkan interaksi manusia di dalamnya. Meskipun masyarakat dan institusi sosial nyata terbentuk dan terlihat secara obyektif, namun di dalamnya dibangun antar subjektifitas anggota masyarakat melalui proses interaksi. Obyektifitas baru bisa terlihat dari subjektifitas kelompok yang memiliki definisi yang sama. Sehingga, manusia melegitimasi makna yang universal untuk mengatur kehidupan sosial dan memberikan makna di dalamnya. $^{49}$

Pandangan tersebut jika dikaitkan dengan banyu manaqib, maka akan terjadi fenomena masing-masing orang percaya ada khasiat dari pembacaan manaqib. Pandangan tersebut kemudian ditegaskan oleh banyak orang secara berulang, lanjut melahirkan dunia secara simbolis yakni meletakkan air di tengah acara majlis zikir Al-Khidmah. Makna simbolik inilah yang nantinya akan memberikan pemahaman sebagai penyembuh berbagai penyakit dan pemuas kebutuhan yang lain sesuai dengan permintaan dan presepsi mereka.

Konstruksi pemahaman jamaah majlis zikir Al-Khidmah jika dilihat dari teori Berger dan Luckman berlangsung melalui proses subjective reality, symbolic reality, dan objective reality. Objective reality merupakan kompleksitas definisi realitas -termasuk keimanan dan ideologi- serta tindakan terulang dan terpola dengan dihayati oleh masyarakat sebagai sebuah fakta. Dalam hal ini menghasilkan sebuah pemahaman subjektif dari individu-individu yang menghasilkan objektive reality berupa banyu manaqib. Symbolic reality merupakan ekspresi simbolik yang dihayati dari

\footnotetext{
${ }^{46}$ Muhammad ibn Ismail Al-Bukhari, Shahih Al-Bukhari, jilid II, juz 25 (Libanon: Dar al-Fikr, 1978), hlm. 99.

${ }^{47}$ A.S. Hamidin, Kebaikan Air Putih (Terapi Air Untuk Penyembuhan, Diet, Kehamilan Dan Kecantikan), hlm. 16.

48 Pangoloan Soleman Ritonga, “"Air" Sebagai Sarana Peningkatan Imtaq (Integrasi Kimia Dan Agama)," Jurnal Sosial Budaya Vol. 8, No. 2 (2011).

${ }^{49}$ I. B. Putera Manuaba, "Memahami Teori Konstruksi Sosial," Jurnal Masyarakat, Kebudayaan Dan Politik Vol. 21, No. 3 (2008): hlm. 221-230.
} 
objective reality. Dalam hal ini berupa tindakan meletakkan ai di tengah acara majlis zikir AlKhidmah. Terakhir, subjective reality merupakan konstruksi definisi yang dimiliki individu dan dikonstruksi melalui proses internalisasi. Realitas subjektif yang dimiliki masing-masing individu merupakan basis untuk melibatkan diri dalam proses eksternalisasi, atau proses interaksi sosial dengan individu lain dalam sebuah struktur sosial. Melalui proses eksternalisasi itulah individu secara kolektif berpotensi melakukan objectivikasi, memunculkan sebuah konstruksi objektive reality yang baru. Dalam hal ini masyarakat percaya bahwa sumber segala nilai adalah bacaan manaqib. ${ }^{50}$

Selain itu juga berlangsung dalam suatu proses dengan tiga momen simultan, yaitu eksternalisasi, objektivikasi dan internalisasi. Pertama, eksternalisasi, yakni proses penyesuaian diri dengan dunia sosio-kultural produk manusia. Tahap pertama ini merupakan bagian yang penting dan mendasar dalam satu pola interaksi antara individu dengan produk-produk sosial masyarakatnya. Yang dimaksud dalam proses ini ialah ketika suatu produk sosial telah menjadi sebuah bagian penting dalam masyarakat yang setiap saat dibutuhkan oleh individu, maka produk sosial itu menjadi bagian penting dalam kehidupan seseorang untuk melihat dunia luar. ${ }^{51}$ Dalam kasus pemahaman jamaah majlis zikir Al-Khidmah terhadap nilai bacaan manaqib dapat dilihat bahwa proses eksternalisasi terjadi ketika jamaah menyesuaikan diri dengan nilai yang sudah berkembang di kalangan jamaah.

Kedua, objektivikasi, yakni interaksi sosial yang terjadi dalam dunia intersubjektif yang disusun atau mengalami institusionalisasi. Pada tahap ini, produk sosial berada dalam proses institusionalisasi, sedang individu atay masyarakat yang berkegiatan memposisikan dirinya sebagai produsen dari dunia tersebut secara bersama. Proses ini bisa berjalan meski anggota masyarakat tanpa bertemu bertatap muka, hanya penyebaran opini saja produk masyarakat bisa berkembang. ${ }^{52}$ Setelah melakukan penyesuaian diri, kemudian terjadilah interaksi antar jamaah majlis zikir AlKhidmah. Proses saling ineraksi antar jamaah majlis zikir Al-Khidmah perihal nilai yang terkandung pada bacaan manaqib (objektivikasi) pada akhirnya mereka memiliki pemahaman dan presepsi yang sama. Semisal, banyu maaqib yang mampu memberikan khasiat sebagai media penyembuhan.

Ketiga, internalisasi, yakni proses individu mengidentifikasi dirinya dengan lembaga-lembaga sosial atau organisasi sosial tempat individu menjadi anggotanya. Terdapat dua pemahaman dasar dari proses internalisasi secara umum; pertama, bagi pemahaman mengenai 'sesama saya' yaitu pemahaman mengenai individu dan orang lain; kedua, pemahaman mengenai dunia sebagai sesuatu yang maknawi dari kenyataan sosial. ${ }^{53}$ Dalam hal ini masing-masing jamaah mengidentifikasi dirinya (internalisasi) tentang kebutuhan yang hendak mereka penuhi melalui/lantaran air tersebut.

\footnotetext{
${ }^{50}$ I. B. Putera Manuaba, Memahami Teori Konstruksi Sosial, hlm. 221-230.

${ }^{51}$ Charles R. Ngangi, “Konstruksi Sosial Dalam Realitas Sosial,” Jurnal ASE Vol. 7, No. 2 (2011): hlm. 1-4.

52 Charles R. Ngangi, "Konstruksi Sosial Dalam Realitas Sosial,"

53 Charles R. Ngangi, "Konstruksi Sosial Dalam Realitas Sosial,"
} 
Bagan 1.

Kontruksi pemahaman secara simultan mengenai banyu manaqib pada jamaah majlis zikir Al-Khidmah

\section{Pemahaman secara Simultan}

\begin{tabular}{|c|c|c|c|c|}
\hline \multirow{2}{*}{ Eksternalisasi } & \multirow{2}{*}{ 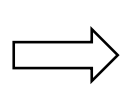 } & \multirow{4}{*}{ > } & \multirow{5}{*}{$\begin{array}{l}\text { Objektive } \\
\text { Subjective } \\
\text { Symbolyc }\end{array}$} & \multirow{6}{*}{$\begin{array}{l}\text { Realitas Terkonstruksi } \\
\text { bahwa Banyu Manaqib } \\
\text { mempunyai khasiat sebagai } \\
\text { media: } \\
\text { 1. Penyembuh penyakit, } \\
\text { 2. Menyapih anak, } \\
\text { 3. Penglaris dagangan, } \\
\text { 4. Pengasihan, } \\
\text { 5. Tangkis rumah, } \\
\text { 6. Menambah kecerdasan, } \\
\text { 7. Penenang hati. }\end{array}$} \\
\hline & & & & \\
\hline & & & & \\
\hline Objektivitas & $\longrightarrow$ & & & \\
\hline & & $\frac{D}{\frac{1}{\lambda}}$ & & \\
\hline Internalisasi & $\longrightarrow$ & 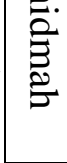 & & \\
\hline
\end{tabular}

Sumber

Pesan

Pergumulan

Efek

\section{Kesimpulan dan Saran}

Sebagai catatan penutup, perlu diambil kesimpulan bahwa ada dua faktor yang mempengaruhi pemahaman masyarakat tentang banyu manaqib, pertama faktor historis, kedua faktor religius. Dulunya masyarakat Indonesia sudah menggunakan air untuk proses penyembuhan yang dinamai dengan istilah suwuk. Tradisi ini kemudian bersentuhan dengan nilai Islam yang akhirnya memunculkan suatu tradisi baru berupa "banyu manaqib." Meski keduanya mempunyai esensi yang sama, namun ada diferensasi di antara keduanya, suwuk yang dibaca adalah mantra, sedang banyu manaqib yang dibaca adalah rangkaian amaliyah manaqib Syeikh Abdul Qadir Al-Jilani ra.

Pemahaman tersebut sejalan dengan cerita Ummu Salamah -istri Rasulullah- yang menyimpan rambut Baginda untuk diberikan kepada para sahabat yang sakit, dengan memasukkan beberapa helai rambut ke dalam air, kemudian air tersebut diminumkan kepada yang bersangkutan untuk mendapatkan kesembuhan dari Allah SWT. Begitupula cerita Abi Usaid yang menggunakan air sumur Buda'ah -yang telah diludahi oleh Rasulullah SAW- untuk diberikan kepada sahabat yang sakit agar memperoleh kesembuhan dari Allah SWT. Cerita di atas mengindikasikan bahwa adanya inang yang digunakan, Ummu salamah dengan rambur, Abu Usaid dengan ludah, sedang jamaah majlis zikir Al-Khidmah dengan bacaan manaqib.

Konstruksi pemahaman di atas jika dilihat dengan teori Berger dan Luckman maka akan berlangsung melalui interaksi dialektis dari subjective reality, symbolic reality, dan objective reality. Subjective reality dalam teori ini, masing-masing individu meyakini bahwa bacaan manaqib adalah sumber nilai. Setelah itu direpresentasikan secara simbolis -symbolic reality- dengan meletakkan air di sekitar tempat pembacaan manaqib. Kemudian gabungan masing-masing individu memunculkan satu objective reality tentang banyu manaqib. Secara simultan juga terjadi proses eksternalisasi, objektifikasi, dan internalisasi. Proses eksternalisasi terjadi ketika jamaah menyesuaikan diri dengan nilai yang sudah berkembang di kalangan jamaah. Kemudian objektifikasi ditandai dengan jamaah yang memiliki pemahaman dan presepsi yang sama. Semisal, 


\section{Sedya Pangasih, Luthfi Rahman \\ RITUAL AGAMA DAN HARMONI SOSIAL KAUM URBAN...}

banyu manaqib yang mampu memberikan khasiat sebagai media penyembuhan. Terakhir, jamaah mengidentifikasi dirinya -internalisasi- tentang kebutuhan yang hendak mereka penuhi melalui/lantaran air tersebut, sehingga muncul suatu tindakan

\section{E. Daftar Pustaka}

Aceh, Abu Bakar. Pengantar Sejarah Sufi Dan Tasawuf. Solo: Romadhoni, 1990.

Al Jalily, Abiel wafa Iie 'Izzati Maulana. MP3 (Manaqib Philoshofi Islami Penyegar Iman Penyejuk Qolbu). Mranggen: Daru Tashfiyyah Eqolbi, 2014.

Al-Bukhari, Muhammad ibn Ismail. Shahih Al-Bukhari. Jilid II, juz 25. Libanon: Dar al-Fikr, 1978.

Al-Ishaqy, Achmad Asrori. Apa Manaqib Itu? Surabaya: Al-Wafa, 2010.

Al-Ishaqy, Ahmad Asrori. Pedoman Kepemimpinan Dan Kepengurusan Dalam Kegiatan Dan Amaliyah Ath- Thariqoh Dan Al Khidmah. Cet. Ke-VIII. Surabaya: Pengurus Pusat Al Khidmah, 2017.

Al-Kaaf, Habib Abdullah Zaqy. Manaqib Syekh Abdul Qodir Al-Jailani: Perjalanan Spiritual Sulthonul Auliya'. Bandung: Pustaka Setia, 2004.

Al-Qahthani, Said bin Musfir. Syaikh Abdul Qadir Al-Jailani. Jakarta: Darul Falah, 2005.

Amri, Saiful. "Peran Manaqib Syaikh Abdul Qadir Aljilani Dalam Meningkatkan Spiritualitas Santri Pondok Pesantren Assalafi Al Fithrah Meteseh.” Skripsi, Fakultas Ushuluddin dan Humaniora UIN Walisongo, 2018.

Atsqalani, Ibn Hajar al-. Sharh Al-Bukhari Fath al-Bari Li Ibni Hajar. Juz 10., n.d.

At-Tadafi, Syaikh Muhammad bin Yahya. Syaikh Abdul Qadir Al-Jailani Mahkota Para Aulia Kemuliaan Hamba Yang Ditampakkan-Nya. Jakarta: Prenada Media, 2005.

Dahlan, Fahrurozi. Tuan Guru: Eksistensi Dan Tantangan Peran Dalam Transformasi Masyarakat. Jakarta: Sanabil, 2015.

Farih, Amin. "Paradigma Pemikiran Tawasul Dan Tabarruk Sayyid Ahmad Ibn Zaini Dahlan Di Tengah Mayoritas Teologi Mazhab Wahabi.” Jurnal Theologia Vol. 27, No. 2 (2016).

Greetz, Clifford. Kebudayaan Dan Agama. Yogyakarta: Kansius, 1992.

Hadi, Sutrisno. Metodologi Research II. Yogyakarta: Andi Offset, 2011.

Hamidin, A.S. Kebaikan Air Putih (Terapi Air Untuk Penyembuhan, Diet, Kehamilan Dan Kecantikan). Yogyakarta: Media Pressindo, 2010.

J. Moleong, Lexy. Metode Peneltian Kualitatif. Bandung: Remaja Rosdakarya, 2015. 


\section{Sedya Pangasih, Luthfi Rahman \\ RITUAL AGAMA DAN HARMONI SOSIAL KAUM URBAN...}

Jannah, Lailatul. "Peran Majelis Dzikir Al Khidmah Dalam Mengembangkan Kecerdasan Spiritual (Studi Pada Jamaah Majelis Dzikir Mahasiswa Al Khidmah Kota Salatiga 2016).” Skripsi, Fakultas Tarbiyah dan Ilmu Keguruan IAIN Salatiga, 2017.

Johansson, Benny. "Functional Water-In Promotion of Health Beneficial Effects and Prevention of Disease." Internal Medicine Review Vol. 3, No. 3 (2016)

Kusumo, Eko Sulistyo. "Bentuk Sinkretisme Islam-Jawa Di Masjid Sunan Ampel Surabaya." Jurnal Mozaik Vol. 15, No. 1 (2015).

Luthviatin, Novia. "Mantra Untuk Penyembuhan Dalam Tradisi Suku Osing Banyuwangi." Jurnal Ikesma Vol. 11, No. 1 (2015).

Mahjudin. Kuliah Akhlak Tasawuf. Jakarta: Kalam Mulia, 1991.

Manuaba, I. B. Putera. "Memahami Teori Konstruksi Sosial.” Jurnal Masyarakat, Kebudayaan Dan Politik Vol. 21, No. 3 (2008)

Ngangi, Charles R. “Konstruksi Sosial Dalam Realitas Sosial.” Jurnal ASE Vol. 7, No. 2 (2011)

Nurdin, Ali. "Komunikasi Magis Dukun (Studi Fenomenologi Tentang Kompetensi Komunikasi Dukun).” Jurnal Komunikasi Vol. 1, No. 5 (2012).

Peter L. Berger dan Thomas Luckmann. The Social Construction of Reality. London: Penguin Books, 1991.

Puslitbang Kehidupan Keagamaan Badan Litbang dan Diklat Kementerian Agama RI. Dinamika Sistem Keagamaan Lokal Di Indonesia. Jakarta: Badan Litbang dan Diklat Kementerian Agama RI, 2012.

Ritonga, Pangoloan Soleman. “"Air” Sebagai Sarana Peningkatan Imtaq (Integrasi Kimia Dan Agama).” Jurnal Sosial Budaya Vol. 8, No. 2 (2011).

Sukmadinata, Nana Syaodih. Metode Penelitian. Bandung: Remaja Rosdakarya, 2015.

Umar, Imron Abu. Kitab Manaqib Tidak Merusak Aqidah Islamiyyah. Kudus: Menara Kudus, 1989.

Wahyudi dan Muhammad Zaini. "Pemahaman Jama'ah Sema'an Al-Qur'an Jantiko Mantab Tentang Banyu Barokah.” Ibda': Jurnal Kajian Islam Dan Budaya Vol. 18, No. 1 (2020). https://doi.org/DOI: 10.24090/IBDA.V18i1.3536.

Yaqin, Muhammad Ainul. "Dzikir Manaqib: Moderasi Islam Di Tengah Masyarakat Multikultural." Proceedings 2nd Annual Conference for Muslim Scholars Kopertais Wilayah IV Surabaya, April 21, 2018.

Yayasan Penyelengga/Penafsir Al-Qur'an Departemen Agama Republik Indonesia. Alhidayah; AlQur'an Tafsir Per Kata Tajwid Dan Kode Angka. Tanggerang Selatan: Kalim, n.d. 